\title{
Cleaved caspase-3 sebagai Uji Apoptosis pada Kanker Serviks IIB Tipe Sel Skuamosa yang Mendapat Kemoterapi Neoadjuvan Cisplatin
}

\author{
Andra Kusuma Putra', Brahmana Askandar', Sjahjenny Mustokoweni ${ }^{2}$ \\ 'Departemen Obstetri dan Ginekologi, ${ }^{2}$ Departemen Patologi Anatomi \\ Fakultas Kedokteran, Universitas Airlangga, RSUD Dr. Soetomo, Surabaya
}

\begin{abstract}
ABSTRAK
Tujuan: mencari peningkatan ekspresi cleaved caspase-3 pada pasien kanker serviks IIB tipe sel skuamosa sesudah pemberian kemoterapi neoadjuvan cisplatin dan mencari kapan waktu yang tepat untuk mendeteksi apoptosis menggunakan cleaved caspase-3. Bahan dan Metode: Jenis penelitian analitik observasional berpasangan. Dilakukan pada penderita kanker serviks IIB tipe sel skuamosa berdasarkan kriteria FIGO yang berobat di POSA RSUD Dr. Soetomo Surabaya. Penelitian dilakukan mulai bulan Mei 2014. Sebelum dilakukan terapi semua penderita diambil biopsi serviks. Kemudian penderita diberikan cisplatin $50 \mathrm{mg} / \mathrm{m} 2 / \mathrm{ming} g u$ Diambil biopsi serviks setelah diberikan kemoterapi ke 1 dan ke 4 (maksimal 8 jam setelah kemoterapi, sampel kedua). Sampel diperiksakan imunohistokimia cleaved caspase 3. Dilakukan penghitungan ekspresi cleaved caspase 3 di bawah mikroskop dengan perbesaran 400x pada 10 lapang pandang. Pengujian statistik dilakukan dengan nilai kemaknaan $\mathrm{p}<0,05$.

Hasil: Rata-rata ekspresi cleaved caspase 3 sebelum kemoterapi adalah $1,46 \pm 1,854$. Setelah kemoterapi ke 1 didapatkan rata- rata $10,77 \pm 3,655$.Setelah kemoterapi ke 4 didapatkan rata- rata $12,77 \pm$ 5,703. Pada pemeriksaan didapatkan ekspresi cleaved caspase 3 setelah pemberian kemoterapi lebih meningkat dibandingkan sebelum pemberian kemoterapi $(\mathrm{p}<0,01)$, sedangkan ekspresi cleaved caspase 3 setelah kemoterapi ke 1 dan ke 4 tidak didapatkan perbedaan bermakna ( $\mathrm{p}=0,882)$.

Simpulan: Pemberian kemoterapi terbukti memberikan efek peningkatan ekspresi cleaved caspase-3. Sehingga cleaved caaspase-3 dapat dijadikan sebagai salah satu uji apoptosis pada efek kemoterapi terhadap sel kanker.
\end{abstract}

Kata kunci: cleaved caspase 3, cisplatin, waktu paruh 8 jam, kanker serviks

\begin{abstract}
Objectives: to identify increased expression of cleaved caspase-3 in IIB squamous cell types cervical cancer patients after neoadjuvant chemotherapy with cisplatin and identifying the right time for detecting apoptosis using cleaved caspase- 3 .

Materials and Methods: paired observational analytic study, performed in patients with IIB squamous cell type cervical cancer based on FIGO criteria who seek treatment at Oncology Clinic, Dr. Soetomo Hospital. The study was conducted from May 2014. Prior to the treatment all patients were subjected to cervical biopsy removal. Then, the patients were given with cisplatin $50 \mathrm{mg} /$ $\mathrm{m} 2 /$ week. Cervical biopsy was taken after being given with chemotherapy to 1 and 4 (up to 8 hours after chemotherapy, the second sample). Samples were subjected to immunohistochemical cleaved caspase 3 examination. We assessed the expression of cleaved caspase 3 under the microscope with 400x magnification on a 10 visual fields. The test was conducted in statistical significance value of $\mathrm{p}<0.05$.

Results: Mean expression of cleaved caspase 3 prior to chemotherapy was $1.46 \pm 1.854$. After chemotherapy 1 the average was $10.77 \pm 3,655$. After chemotherapy 4 the average was $12.77 \pm$ 5.703. In examination, the expression of cleaved caspase 3 obtained after administration of chemotherapy increased more than that before the administration of chemotherapy ( $p<0.01)$, whereas the expression of cleaved caspase 3 after chemotherapy 1 and 4 was not significantly different $(\mathrm{p}=0.882)$.

Conclusion: chemotherapy proved to give the effect of increased expression of cleaved caspase-3. Thus cleaved caaspase- 3 can be used as an apoptosis test in the effects of chemotherapy on cancer cells.
\end{abstract}

Keywords: cleaved caspase 3, cisplatin, half-life 8 hours, cervical cancer

Correspondence: Andra Kusuma Putra, Departmen Obstetri dan Ginekologi, Fakultas Kedokteran Universitas Airlangga, RSUD dr. Soetomo Surabaya, Jl Prof. Dr. Moestopo 6 - 8, Surabaya. Email :

\section{PENDAHULUAN}

Kanker merupakan salah satu penyakit pembunuh manusia terbesar setelah penyakit jantung. Data dari Kementerian Kesehatan (Kemenkes) tahun 2012 menyebutkan, prevalensi kanker mencapai 4,3 banding 1.000 orang. Sel tubuh manusia berasal dari mitosis dan hampir semuanya akan mati oleh apoptosis. Kanker terjadi jika keseimbangan tersebut terganggu, baik oleh karena peningkatan proliferasi sel maupun penurunan kematian sel. Tujuan akhir terapi kanker adalah untuk membuat sel kanker mati tanpa menyebabkan kerusakan sel normal terlalu banyak. Pada beberapa kasus dimana terdapat resistensi terhadap apoptosis mungkin bisa menjelaskan mengapa terapi kanker bisa gagal. ${ }^{1}$

Kanker serviks merupakan kanker terbanyak kedua pada wanita di seluruh dunia setelah kanker payudara.Insiden penyakit ini lebih tinggi di negara berkembang dibanding negara maju dimana program skrining yang telah dilakukan bisa mengurangi insiden dan kematian. Pilihan terapi pada stadium awal adalah pembedahan dengan angka ketahanan hidup 5 tahun 85 hinga 95\%, sedangkan pada stadium lanjut memerlukan beberapa pendekatan terapi untuk mencapai kelangsungan hidup yang baik. ${ }^{2}$ 
Sampai tahun 1983, kanker serviks dianggap sebagai kanker kemoresisten dan diobati dengan kemoterapi hanya setelah semua pengobatan lain gagal. Setelah penemuan bahwa kanker serviks adalah kanker yang kemosensitif maka strategi menggunakan kemoterapi sebagai neoadjuvan baik untuk pembedahan atau radioterapi meningkat. Pada tahun 1983, Friedlander telah melaporkan studi pertama mengenai penggunaan kemoterapi primer. Sejak itu, banyak penelitian dipublikasikan tentang penggunaan kemoterapi sebagai pengobatan neoadjuvan (kemoterapi neoadjuvan) sebelum operasi atau sebelum radiasi. ${ }^{3}$

Pada kanker serviks stadium lanjut, yaitu IIB-IVA, FIGO merekomendasikan terapi baku yaitu radiasi eksterna dan brakhiterapi, bersamaan dengan kemoterapi yang dikenal dengan sebutan kemoradiasi. Di RSUD Dr. Soetomo, terapi kanker serviks mengikuti rekomendasi yang dikeluarkan oleh Federation Internationale de Gynecologie et d'Obstetrique (FIGO). Tetapi khusus pada kanker serviks IIB Divisi Ginekologi Onkologi RSUD Dr. Soetomo menetapkan kebijakan terapi yang berbeda dari rekomendasi FIGO. Divisi Ginekologi Onkologi menetapkan terapi kanker serviks IIB meliputi pemberian kemoterapi neoajuvan platinum based dilanjutkan histerektomi radikal (Gambar 1). Di Surabaya, dalam hal ini data yang didapatkan dari jumlah kunjungan Poli Onkologi Satu Atap pada tahun 2013, ada 8.340 penderita (664 penderita baru) kanker serviks.

Penelitian mengenai penilaian apoptosis pada pasien kanker serviks IIB setelah pemberian kemoterapi neoadjuvan sudah pernah dilakukan sebelumnya. Pada penelitian sebelumnya didapatkan penurunan ekspresi cleaved caspase-3 setelah pemberian kemoterapi cisplatin selama $4 \mathrm{x}$ dengan interval 1 minggu. Hal ini tidak sesuai dengan hipotesis penelitian bahwa didapatkan peningkatan cleaved caspase-3 setelah pemberian kemoterapi neoadjuvan cisplatin, sehingga pada penelitian ini terlihat bahwa cleaved caspase-3 tidak bisa dijadikan marker untuk melihat apoptosis karena dari pengamatan sediaan hematoxylin eosin didapatkan sel kanker viabel menurun setelah pemberian kemoterapi. Waktu pengambilan sampel post kemo-terapi bisa menjadi faktor penyebab tidak terdeteksinya apoptosis menggunakan cleaved caspase-3 karena proses aktivasi caspase tersebut sudah terlewati. Semua evaluasi pasien kanker serviks IIB post kemoterapi neoadjuvan dilakukan 1 minggu setelah pemberian cisplatin keempat dan oleh karena hasil evaluasi semua pasien masih inoperable maka pengambilan biopsi ulangan dilakukan pada saat itu juga dan pada pasien tersebut diberikan kemoterapi paclitaxel carboplatin $3 x^{4}$

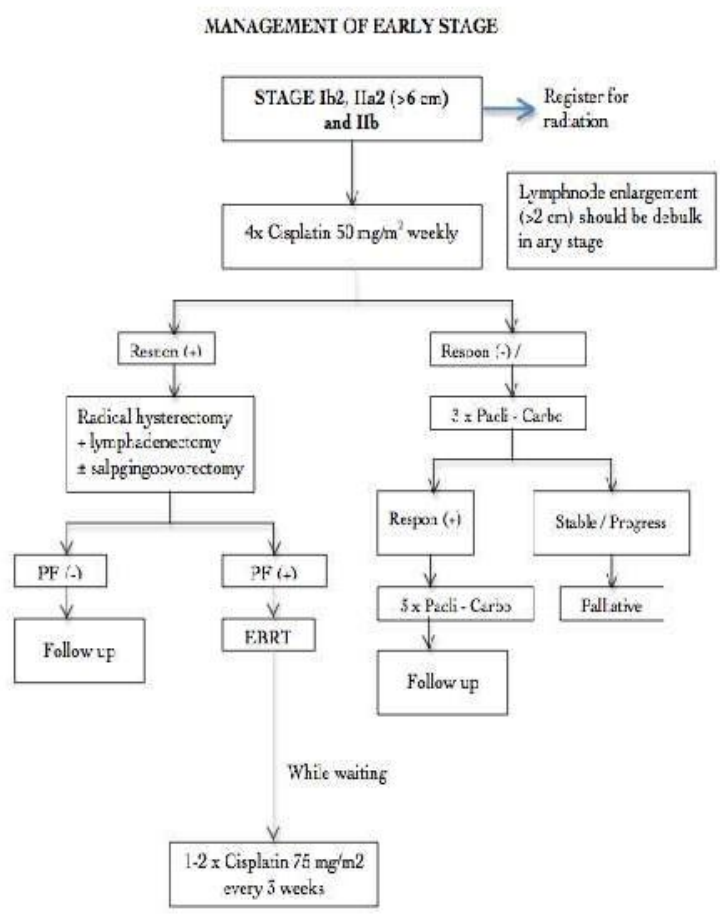

Gambar 1. Protokol kanker serviks stadium IIB

\section{BAHAN DAN METODE}

Apoptosis merupakan bentuk kematian sel yang terprogram yang melibatkan beberapa gen yang berperan penting dalam penghancuran sel. Hipotesis penelitian ini yaitu terdapat peningkatan cleaved caspase-3 pada kanker serviks IIB tipe sel skuamosa sesudah pemberian kemoterapi neoadjuvan cisplatin.

Jenis penelitian ini adalah analitik observasional berpasangan. Dilakukan pada penderita kanker serviks IIB tipe sel skuamosa berdasarkan kriteria FIGO. Dilakukan pemeriksaan imunohistokimia cleaved caspase 3 sebelum dan sesudah pemberian cisplatin $50 \mathrm{mg} / \mathrm{m} 2 / \mathrm{minggu}$. Populasi dan Sampel adalah penderita Kanker serviks IIB berdasarkan kriteria FIGO yang berobat di Poliklinik Onkologi Satu Atap (POSA) RSUD Dr. Soetomo Surabaya. Kriteria inklusi: Penderita Kanker serviks stadium IIB menurut kriteria FIGO dengan hasil biopsi PA: Karsinoma Sel Skuamosa (Squamous cell carcinoma-SCC). Kriteria eksklusi terdiri atas terdapat keganasan lain pada penderita kanker serviks IIB, terdapat riwayat kemo-terapi/radiasi sebelumnya, terdapat kelainan fungsi ginjal, liver. Variabel bebas adalah terapi Cisplatin $50 \mathrm{mg} / \mathrm{m} 2 /$ minggu dan Variabel tergantung adalah Cleaved caspase-3. 
Waktu penelitian dimulai bulan Mei 2014. Seluruh sampel yang digunakan dipilih berdasarkan kriteria inklusi dan eksklusi. Sebelum dilakukan terapi semua penderita diambil biopsi serviks (sampel pertama). Sampel dibawa ke bagian Patologi Anatomi RSDS dan diperiksakan imunohistokimia cleaved caspase-3. Penderita diberikan cisplatin $50 \mathrm{mg} / \mathrm{m}^{2} /$ minggu. Diambil biopsi serviks setelah diberikan kemo-terapi ke 1 dan ke 4 (maksimal 8 jam setelah kemoterapi selesai). Sampel dibawa ke bagian Patologi Anatomi RSDS dan diperiksakan imunohistokimia cleaved caspase-3.

\section{HASIL DAN PEMBAHASAN}

Penelitian ini dilakukan pada 13 pasien kanker serviks IIB. Dari seluruh penderita didapatkan usia rata- rata adalah 52,46 tahun dengan usia termuda 44 tahun dan tertua 64 tahun.

Distribusi hasil biopsi PA Karsinoma Sel Skuamosa (Squamous Cell Carcinoma-SCC) didapatkan 46,2\% adalah Invasive Keratinizing Squamous Cell Carcinoma dan 53,8\% Invasive Non Keratinizing Squamous Cell Carcinoma. Setelah dilakukan pemeriksaan biopsi seluruh pasien yang memenuhi kriteria inklusi diberikan kemoterapi neoadjuvan cisplatin $50 \mathrm{mg} / \mathrm{m} 2$ dengan interval 1 minggu selama $4 \mathrm{x}$ sesuai prosedur tetap di bagian Onkologi Gineologi Fakultas Kedokteran
Universitas Airlangga/RSUD Dr. Soetomo Surabaya. Total cisplatin yang diberikan pada pasien rata- rata adalah $275,10 \mathrm{mg}$.

Setelah dilakukan pengecatan, dari pemeriksaan dengan hematoxylin eosin (HE) didapatkan bahwa setelah pemberian kemoterapi terjadi penurunan sel kanker yang masih viable dibandingkan sebelum kemoterapi, dan apabila dibandingkan antara pemeriksaan setelah kemoterapi ke 4 makin sedikit sel kanker viable jika dibandingkan dengan pemeriksaan setelah kemoterapi pertama (Gambar 2). Hal ini sesuai dengan tujuan kemoterapi yaitu untuk membunuh sel kanker. Selanjutnya dilakukan pemeriksaan imunohistokimia cleaved caspase-3. Dilakukan pemeriksaan dengan menghitung jumlah sel yang mengandung ekspresi cleaved caspase3 dengan pembesaran 400x dalam 10 lapang pandang. Pada pemeriksaan didapatkan ekspresi cleaved caspase 3 setelah pemberian kemoterapi lebih meningkat dibandingkan sebelum pemberian kemoterapi, sedangkan ekspresi cleaved caspase 3 setelah kemoterapi ke 1 dan ke 4 tidak didapatkan perbedaan bermakna (Gambar 3). Jika dihitung, pada pemeriksaan cleaved caspase 3 didapat-kan nilai rata- rata sebelum kemoterapi adalah 1,46 dengan nilai minimum 0 dan maksimum 6. Setelah kemoterapi ke 1 didapatkan rata-rata 10,77 dengan nilai minimum 7 dan maksimum 17. Setelah kemoterapi ke 4 didapatkan rata-rata 12,77 dengan nilai minimum 2 dan maksimum 21 (Tabel 1).
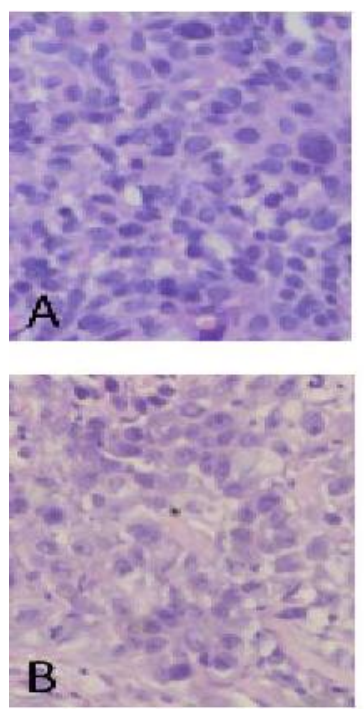
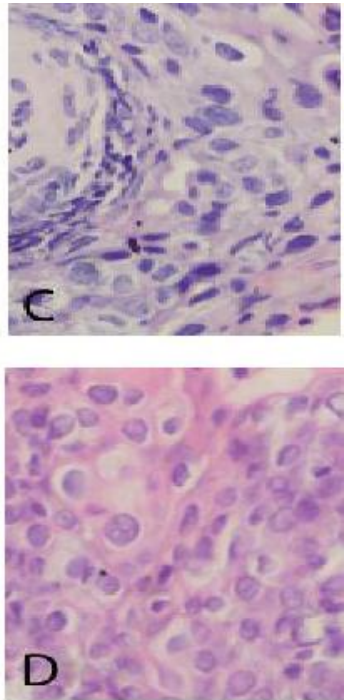
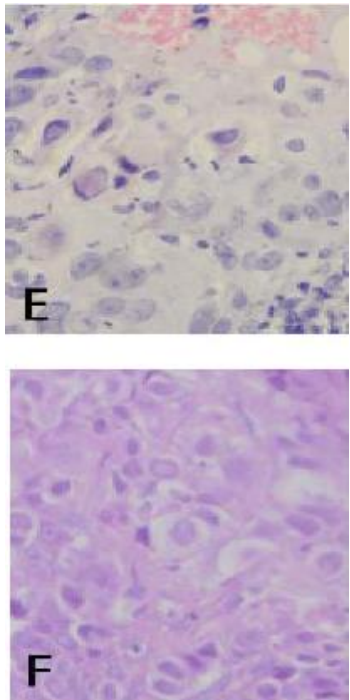

Gambar 2. Pengecatan HE sampel biopsi serviks. Pengecatan HE biopsi serviks keratinizing SCC (A) dan non keratinizing SCC (B) pre NAC, tampak sel kanker yang penuh. Pengecatan HE biopsi serviks keratinizing SCC (C) dan non keratinizing SCC (D) post NAC yang ke 1, tampak sebagian inti sel kanker yang sudah mati. Pengecatan HE biopsi serviks keratinizing SCC (E) dan non keratinizing SCC (F) post NAC yang ke 4, tampak lebih banyak inti sel kanker yang sudah mati 

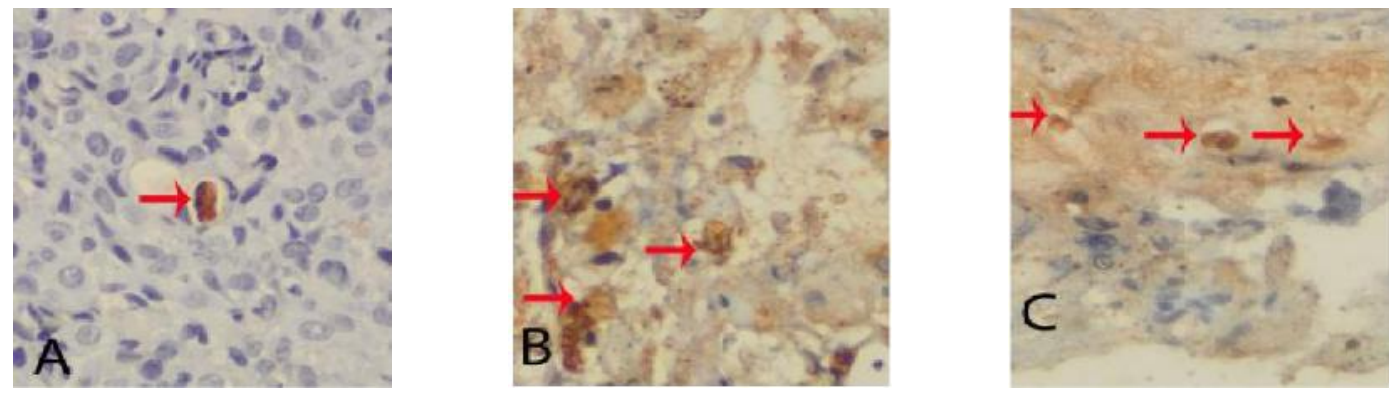

Gambar 3. Pengecatan IHC cleaved caspase 3 sampel biopsi serviks. Pengecatan pre NAC tampak ditemukan sedikit aktifitas caspase 3 (A) bila dibandingkan dengan post NAC ke 1 (B) dan post NAC ke 4 (C).

Tabel 1. Nilai ekspresi antara masing-masing pemeriksaan

\begin{tabular}{lccc}
\hline & Mean & Std. Deviation & $\mathrm{N}$ \\
\hline Ekspresi cleaved caspase-3 pre NAC & 1.46 & 1.854 & 13 \\
Ekspresi cleaved caspase-3 post NAC 1 & 10.77 & 3.655 & 13 \\
Ekspresi cleaved caspase-3 post NAC 4 & 12.77 & 5.703 & 13 \\
\hline
\end{tabular}

Tabel 2. Perbandingan ekspresi antara masing-masing pemeriksaan

\begin{tabular}{clccc}
\hline Faktor & \multicolumn{1}{c}{ Faktor } & Mean Difference & Std. Error & Sig. $^{\text {b }}$ \\
\hline Pre kemoterapi & Post kemoterapi 1 & $-9.308^{*}$ & 1.322 & .000 \\
& Post kemoterapi 4 & $-11.308^{*}$ & 1.478 & .000 \\
\multirow{2}{*}{ Post kemoterapi 1 } & Pre kemoterapi & $9.308^{*}$ & 1.322 & .000 \\
& Post kemoterapi 4 & $-2.000^{*}$ & 1.822 & .882 \\
Post kemoterapi 4 & Pre kemoterapi & $11.308^{*}$ & 1.478 & .000 \\
& Post kemoterapi 1 & 2.000 & 1.822 & .882 \\
\hline
\end{tabular}

Data diuji dengan Shapiro-Wilk test dimana didapatkan hasil distribusi data yang normal sehingga dilanjutkan dengan Repeated annova didapatkan hasil $\mathrm{p}=<0,001$ $(p<0,05)$. Hal ini menunjukkan bahwa didapatkan peningkatan yang bermakna terhadap pemeriksaan imunohistokimia cleaved caspase 3. Dilakukan tes Post hoc Bonferroni untuk menjabarkan, didapatkan antara ekspressi cleaved caspase 3 pre kemoterapi dengan ekspressi cleaved caspase 3 post kemoterapi ke 1 dan ke 4 didapatkan $\mathrm{p}=<0,001(\mathrm{p}<0,05)$.

Hal ini menunjukkan bahwa didapatkan peningkatan yang bermakna. Sedangkan ekspressi cleaved caspase 3 post kemoterapi ke 1 dan ekspressi cleaved caspase 3 post kemoterapi ke 4 didapatkan $\mathrm{p}=0,882$ ( $\mathrm{p}>0,05)$ sehingga menunjukkan tidak ada perbedaan bermakna. (Tabel 2). Pada perbandingan antara ekspresi cleaved caspase 3 dengan kondisi operabilitas pasien, didapat- kan tidak ada korelasi antara tingkat ekspresi dengan keberhasilan terapi menjadi operasi.

\section{Karakteristik subyek penelitian}

Pada penelitian ini, jumlah pasien yang dilakukan pemeriksaan berjumlah 13 orang.Umur pasien kanker serviks IIB yang berobat ke RSUD Dr. Soetomo ratarata berusia 52,46 tahun. Hal ini sesuai dengan studi epidemiologi yang menyatakan kanker serviks merupakan kanker usia reproduktif. Rata- rata usia penderita di dunia adalah 51,4 tahun dan didapatkan kecendurungan peningkatan kanker serviks dengan meningkatnya usia penderita, hal ini diduga karena pada usia lebih tua tidak melakukan skrining sebaik pada saat usia muda. ${ }^{5}$

Penelitian ini dilakukan pada penderita dengan hasil biopsi PA Karsinoma Sel Skuamosa (Squamous Cell 
Carcinoma-SCC) dimana didapatkan 46,2\% adalah Invasive Keratinizing Squamous Cell Carcinoma dan 53,8\% Invasive Non Keratinizing Squamous Cell Carcinoma. Alasan dipilih jenis histopatologi Sel Skuamosa karena merupakan jenis histopatologi terbanyak. Kanker serviks berjenis karsinoma sel skuamosa, yang berasal dari ektoserviks ditemukan sekitar $85 \%$ dari total kanker serviks. ${ }^{5}$

Pada penelitian ini diberikan cisplatin $50 \mathrm{mg} / \mathrm{m}^{2} / \mathrm{minggu}$ sebanyak $4 x$, dan dosis total cisplatin pada penelitian ini rata- rata adalah $275.1023 \mathrm{mg}$. Pada beberapa pusat onkologi dan penelitian yang ada diberikan dosis kemoterapi cisplatin yang berbeda-beda, baik sebagai agen tunggal maupun kombinasi. ${ }^{6}$

\section{Ekspresi cleaved caspase 3}

Pada pengecatan hematoxylin eosin sediaan blok parafin didapatkan perbedaan antara sesudah kemoterapi cisplatin didapatkan jaringan tumor yang sudah tidak viabel. Pada sampel sebelum kemoterapi cisplatin didapatkan banyak sel kanker yang viabel, setelah diberikan kemoterapi ke 1, sebagian sel kanker menjadi tidak viabel dan semakin banyak lagi setelah kemoterapi ke 4.

Pada penelitian ini, didapatkan ekspresi cleaved caspase 3 pre kemoterapi sekitar $1,46 \pm 1,854$. Apabila dibandingkan dengan ekspresi cleaved caspase 3 post kemoterapi ke 1 , yang bernilai $10,77 \pm 3,655$, secara statistik didapatkan peningkatan yang bermakna. Sedangkan apabila dibandingkan dengan ekspresi cleaved caspase 3 post kemoterapi ke 4 , yang bernilai $12,77 \pm 5,703$, secara statistik juga didapatkan peningkatan yang bermakna. Hal ini sesuai dengan hipotesa penelitian bahwa terdapat peningkatan cleaved caspase 3 pada kanker serviks IIB tipe sel skuamosa sesudah pemberian kemoterapi neoadjuvan cisplatin.

Perbandingan ekspresi cleaved caspase 3 setelah pemberian kemoterapi ke 1 dan kemoterapi ke 4 di-dapatkan secara statistik tidak ada perbedaan bermakna, meskipun secara klinis bila dilihat terjadi peningkatan rerata walau sedikit. Hal ini menunjukkan bahwa pada pemberian pertama kemoterapi sudah didapakan proses apoptosis sel kanker, dan menjadi lebih efektif bila diberikan secara berulang. terlihat dari hasil pengecatan HE yang menunjukkan sel kanker yang makin berkurang. Pemberian kemoterapi berdasarkan kinetika sel adalah membunuh sel berdasarkan fraksi sel yang konstan bukan jumlah sel yang konstan.Pemberian kemoterapi pertama dapat membunuh 2 sampai 4 log sel. Bila satu populasi kanker sebanyak $10^{2}$ (1 kg tumor) diberikan dosis tunggal kemoterapi, sebagian besar sel kanker hilang, tetapi tidak dapat menghilangkan tumor tersebut secara tuntas. Oleh karena itu, diperlukan pemberian kemoterapi ulangan secara intermitten.,

Jika dibandingkan penelitian sejenis sebelumnya dimana hasil penelitian tidak sesuai dengan hipotesa adanya peningkatan ekspresi cleaved caspase 3 setelah pemberian kemoterapi. ${ }^{4}$ Disimpulkan bahwa apakah memang cleaved caspase-3 tidak bisa menjadi indikator apoptosis sehingga memerlukan metode lain untuk memeriksa apoptosis, atau kesalahan waktu pengambilan sampel sehingga apoptosis sudah tidak terdeteksi. Pada penelitian ini sampel diambil maksimal 8 jam setelah kemoterapi (dibandingkan dengan penelitian sebelumnya yang diambil 1 minggu post kemoterapi) dan didapatkan hasil yang sesuai hipotesa penelitian. Dasar pemilihan waktu pengambilan adalah keputusan peneliti dengan mempertimbangkan beberapa pustaka. Penelitian in vitro mengenai perubahan kaspase 3 aktif, kaspase 7 aktif dan c-PARP pada sel kanker sebelum dan sesudah pemberian paclitaxel dan Photo Dynamic therapy (PDT) pada sel tumor, pengambilan bahan dilakukan 24 jam setelah pemberian perlakuan dan didapatkan peningkatan ketiga marker tersebut dibandingkan kelompok kontrol. ${ }^{8}$ Pada penelitian mengenai marker apoptosis yaitu DFF40 (cleaved DNA Fragmentation Factor-40), Bax, Bcl-2, caspase-3, caspase-6 pada kanker payudara sebelum dan sesudah kemoterapi tamoxifen. Dilakukan biopsi sebelum tindakan dan biopsi 24 jam setelah kemoterapi. Didapatkan peningkatan pada DFF40, Bax dan caspase 624 jam setelah pemberian kemoterapi tetapi tidak pada caspase-3 dan Bcl-2. ${ }^{9}$ Sedangkan penelitian terbaru yang dikatakan waktu paruh dari caspase-3 adalah 8 jam. ${ }^{10}$

Pada evaluasi operabilitas didapatkan hanya ada 2 pasien yang dinyatakan operabel. Secara statistik apabila dihitung secara statistik, tidak didapatkan korelasi antara nilai ekspresi cleaved caspase-3 pre kemoterapi dan post kemoterapi dengan kondisi operabilitas pasien. Hal ini sejalan dengan penelitian yang yang menyatakan secara umum tidak terdapat perbedaan bermakna penilaian keberhasilan operabilitas (pra-operatif) pada penderita yang mendapat kemoterapi neoajuvan cisplatin dan paclitaxel-carboplatin. ${ }^{11}$

\section{SIMPULAN}

Pemberian kemoterapi terbukti memberikan efek peningkatan ekspresi cleaved caspase-3. Sehingga cleaved caspase-3 dapat dijadikan sebagai salah satu uji apoptosis pada efek kemoterapi terhadap sel kanker. Kelemahan lain penelitian ini adalah waktu pengambilan sampel yang tidak seragam dan tujuan akhir terapi yaitu operabilitas kurang bisa dihubungkan 
dengan ekspresi cleaved caspase-3 karena bersifat subjektif.

\section{DAFTAR PUSTAKA}

1. Gerl R, Vaux DL. Apoptosis in the development and treatment of cancer. Carcinogenesis. 2005;26(2):263-70.

2. Espaillat R, Rose PG. Management of Locally Advanced Cervical Cancer. Ohio USA: Lippincott Williams and Wilkins; 2005. p. 1040-8746.

3. Benedetti P. An update in neoadjuvant chemotherapy in cervical cancer. Gynecol Oncol. 2007;107:20-2.

4. Rusiyanti, Askandar B. Perubahan Ekspresi Cleaved caspase 3 pada kanker serviks IIB sebelum dan sesudah pemberian Kemoterapi Neoadjuvan Cisplatin. Departemen/SMF Ilmu Kebidanan dan Kandungan/Fakultas Kedokteran Universitas Airlangga RSUD dr. Soetomo Surabaya. 2013.

5. Berek JS, Hacker NF. Practical Gynecology Oncology. 14th Eds. Philadelphia: Lippincott Williams and Wilkins; 2007. p. 3-30.

6. Tierney J. Neoadjuvant Chemoteraphy for Locally Advanced Cervical Cancer : a meta analysis review and meta analysis of individual patient data from 21 randomised Trials. Eur J Cancer. 2003;39(17): 2470-86.

7. Edianto D. Kanker Serviks, dalam Onkologi Ginekologi. Edisi ke-1. Jakarta: Yayasan Bina Pustaka Sarwono Prawirohardjo; 2006. h. 442-55.

8. Bressenot et al. Assessment of apoptosis by immunohistochemistry to active caspase-3, active caspase-7, or cleaved PARP in monolayer cells and spheroid and subcutaneous xenografts of human carcinoma. J Histochem Cytochem. 2009;57(4): 289-300.

9. Parton $\mathrm{M}$, et al. Coordinate Expression of Apoptosis-associated Proteins in Human Breast cancer before and during Chemotherapy. London, UK. Clin Cancer Res. 2002;8(7):2100-8.

10. Walsh JG, Logue SE, Luthi AU, Martin SJ. Caspase-1 Promiscuity is Counterbalanced by Rapid Inactivation of Processed Enzyme. J. Biol. Chem. 2011;286:32513-24.

11. Friyadi M.H, Askandar B. Perbandingan Operabilitas Setelah Pemberian. Kemoterapi Neoajuvan Cisplatin dan Paclitaxel Carboplatin Pada Kanker Serviks IIB di Divisi Ginekologi Onkologi RSUD Dr. Soetomo Surabaya. Depar-temen/SMF Ilmu Kebidanan dan Kandungan, Fakultas Kedokteran Universitas Airlangga RSUD dr. Soetomo Surabaya. 2014. 